International Review of Social History 45 (2000), pp. 449-474

(C) 2000 Internationaal Instituut voor Sociale Geschiedenis

\title{
Women, Other "Fresh" Workers, and the New Manufacturing Workforce of Interwar Britain*
}

\author{
PETER SCOTT
}

Summary: Structural, organizational, and technological changes in British industry during the interwar years led to a decline in skilled and physically demanding work, while there was a dramatic expansion in unskilled and semiskilled employment. Previous authors have noted that the new un/semiskilled jobs were generally filled by "fresh" workers recruited from outside the core manufacturing workforce, though there is considerable disagreement regarding the composition of this new workforce. This paper examines labour recruitment patterns and strategies using national data and case studies of eight rapidly expanding industrial centres. The new industrial workforce is shown to have been recruited from a "reserve army" of workers with the common features of relative cheapness, flexibility, and weak unionization. These included women, juveniles, local workers in poorly paid nonindustrial sectors, such as agriculture, and (where these other categories were in short supply) relatively young long-distance internal migrants from declining industrial areas.

During the interwar years structural, organizational, and technological changes had far-reaching effects on the nature of manufacturing work in

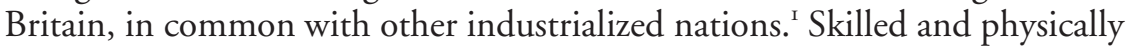
demanding work became less prevalent, while there was a dramatic expansion in unskilled and semiskilled employment. ${ }^{2}$ Glucksmann, Heim, and Savage have all highlighted the fact that these new un/semiskilled jobs were filled by a new workforce recruited from "fresh" nonindustrial workers, who

* I would like to thank Stephen Bunker, Stephen Drinkwater, and Tim Rooth for their comments on earlier drafts of this paper. Thanks are also due to Tim Hatton and Roy Bailey, for allowing me access to papers unpublished at the time of writing, and to the staff of the Letchworth Museum; London Metropolitan Archives; Modern Records Centre, Warwick; Nuffield College Library, Oxford; Public Record Office; Watford Museum; and Welwyn Garden City Library, for their generous help with my research. Any errors or omissions are my own.

I. For examples from the Netherlands and US, see Gertjan de Groot and Marlou Schrover, "Between Men and Machines: Women Workers in New Industries, I870-1940", Social History, 20 (1995), pp. 279-296; Ruth Milkman, "Female Factory Labor and Industrial Structure: Control and Conflict over 'Woman's Place' in Auto and Electrical Manufacturing”, Politics and Society, I2 (1983), pp. 159-203.

2. Kevin Whitston, "Worker Resistance and Taylorism in Britain", International Review of Social History, 42 (1997), pp. I-24. 
were both cheaper and more adaptable than workers displaced from declining industries. However, their views regarding the composition of this new workforce differ substantially. Glucksmann places overriding emphasis on female employment, arguing that during this period women came to constitute the "prime workforce" for assembly line work, "occupying a position in the division of labour which was assigned to them alone". Heim also notes the importance of female labour, but highlights agricultural and young workers as additional types of preferred labour. ${ }^{4}$ Savage has argued that, while the "new industries" did employ "some women in specific areas of production, the stark fact is that the majority of these new jobs went to men". 5 He suggests that youth labour and disadvantaged ethnic groups (such as Welsh migrants) formed important alternative sources of cheap labour to women.

This debate reflects differences in theoretical perspectives regarding the causes of job segregation. Marxist-feminists have concentrated on segregation by gender, in the context of women's general subordination in advanced capitalist societies. Much work using this perspective has emphasized similarities between women's role in wage and family labour, suggesting that job segregation was modelled on women's employment in tasks analogous to those they traditionally undertook in the home. However, since housework consists of an almost infinite variety of tasks, such comparisons have limited explanatory power and have even been used to justify women's wartime employment in jobs which were previously viewed as embodying the very essence of masculinity. ${ }^{6}$

Labour market segmentation models, originally developed to explain the exclusion of a variety of disadvantaged workers from jobs with better pay and conditions, provide a theoretical framework for employment segregation which can be applied both to women and to other groups with whom they share low-status jobs, such as juveniles and ethnic minorities. Milkman has argued that, while such theories offer valuable insights, they pay insufficient attention to the special factors associated with the delineation of jobs by gender, which involve political struggles over "women's place" in the labour market - for example, through union resistance to the substitution of women for men. ${ }^{7}$

3. Miriam Glucksmann, Women Assemble: Women Workers and the New Industries in Interwar Britain (London, 1990), p. 2.

4. Carol E. Heim, "Structural Transformation and the Demand for New Labor in Advanced Economies: Interwar Britain”, Journal of Economic History, 44 (1984), pp. 585-595, 587. Glucksmann also notes that employers preferred young workers, but regards these as a subgroup of females rather than a separate category of both male and female labour.

5. Mike Savage, “Trade Unionism, Sex Segregation, and the State: Women's Employment in

'New Industries' in Inter-war Britain”, Social History, I3 (1988), pp. 209-230, 210.

6. Milkman, "Female Factory Labor", p. I6I.

7. Ibid., pp. 164-165. 
This article examines the composition of the new manufacturing workforce in Britain using national data, together with case studies of eight industrial centres which experienced rapid expansion during this period. These show a pattern of recruitment more complex than that portrayed by Glucksmann, Heim, or even Savage - including groups of workers that he does not consider, such as former agricultural labourers and a variety of local urban workers. Employers opportunistically recruited workers from a reserve army of labour, whose characteristics were determined by the multiple dimensions of gender, age, previous employment, and location. The allocation of jobs between these groups is analysed using a labour market segmentation perspective. It is found that, while Milkman's arguments regarding political struggles over the allocation of jobs between men and women are relevant, similar struggles also took place with regard to the substitution of juveniles and migrants for local adult males.

\section{WAGE DIFFERENTIALS AND EMPLOYMENT STRATEGIES}

In order to test the arguments of Heim, Savage, and Glucksmann, it is important to establish both the age and gender composition of the manufacturing workforce, and their wage differentials. A 1935 official survey provides the best available data, summarized (for manufacturing sectors) in Table I overleaf. For all industries covered (including some nonmanufacturing trades) average weekly earnings were 64.5 shillings for men aged over twenty-one, 3I.3 shillings for women over eighteen, 23.0 shillings for males under twenty-one and 16.3 shillings for females under eighteen. ${ }^{8}$ More disaggregated evidence regarding wage differentials for younger workers can be gained from social surveys of Welwyn Garden City and Watford. The Welwyn survey, conducted in 1939, indicated that average weekly wages for workers aged sixteen to twenty-one were 33 shillings for boys and 28 shillings for girls, while both boys and girls aged fourteen to sixteen averaged only I6.75 shillings. In addition to gender differentials narrowing for younger workers, these also had lower sectoral wage differentials. ${ }^{9}$ Similarly, the Watford survey, conducted in around 1933, showed narrower gender wage differentials for younger juveniles, together with strong age differentials for boys - rising from I2.5 to I5 shillings, for ages fourteen to fifteen, to I5 to 17.5 shillings at fifteen to sixteen, and 20 to 30 shillings at sixteen to eighteen. ${ }^{10}$

Table I also reveals considerable differences between industries regarding

8. Ministry of Labour Gazette (July 1937), pp. 257-258.

9. Jacqueline Tyrewhitt, "Life and Labour in Welwyn Garden City", typescript, 1939 [hereafter, Tyrewhitt, Welwyn Survey], Welwyn Garden City Library, Sir Frederic Osborn Archive, K256. IO. Civic Survey Council, "Watford Civic Survey 1933”, [hereafter, Watford Civic Survey], vols 2 and 3, manuscript, c. 1933, Watford Library. 
Table I. Average weekly wages and employment distribution by age and gender in October 1935

\begin{tabular}{|c|c|c|c|c|c|c|c|c|}
\hline & \multirow{2}{*}{$\begin{array}{c}\text { Men's } \\
\text { wages } \\
\text { (shillings) }\end{array}$} & \multicolumn{3}{|c|}{$\begin{array}{l}\text { Relative wages } \\
\text { (\% of men) }\end{array}$} & \multicolumn{4}{|c|}{$\begin{array}{c}\text { Employment } \\
\text { distribution (\%) }\end{array}$} \\
\hline & & Women & Boys & Girls & Men & Women & Boys & Girls \\
\hline Textiles & 55.9 & 54.20 & 41.32 & 30.77 & 33.63 & 47.41 & 7.17 & 11.79 \\
\hline Woodworking industries & 65.1 & 51.92 & 33.64 & 23.96 & 67.06 & 7.61 & 22.23 & 3.10 \\
\hline Clothing & 64.5 & 50.70 & 34.73 & 23.26 & 20.29 & 54.86 & 6.37 & 18.48 \\
\hline Food, drink, and tobacco & 63.7 & 50.39 & 39.09 & 26.69 & 49.73 & 29.00 & 8.87 & 12.40 \\
\hline Non-metallic mineral products & 60.7 & 47.94 & 46.62 & 28.50 & 87.78 & 1.10 & 10.60 & 0.52 \\
\hline Leather & 61.8 & 47.73 & 36.89 & 24.76 & 58.69 & 18.45 & 14.93 & 7.92 \\
\hline Chemicals, bricks, pottery, glass & 63.0 & 46.67 & 38.73 & 24.29 & 67.16 & 13.75 & 12.83 & 6.27 \\
\hline Other manufacturing & 64.9 & 46.38 & 38.67 & 25.12 & 49.07 & 26.98 & 12.38 & 11.57 \\
\hline Metal and engineering industries & 67.6 & 46.01 & 32.99 & 25.59 & 67.79 & 10.39 & 17.99 & 3.83 \\
\hline Paper and printing & 83.7 & 39.90 & 27.36 & 18.52 & 52.51 & 25.00 & 10.78 & 11.72 \\
\hline Average of sectors & 65.1 & 48.18 & 37.01 & 25.14 & 55.37 & 23.45 & 12.41 & 8.76 \\
\hline
\end{tabular}

Source: Ministry of Labour Gazette (February 1937), pp. 46-48; (March 1937), pp. 88-89; (April 1937), pp. 133-135; (May 1937), pp. I74-176; (July 1937), pp. 257-258.

Notes: "Women" refers to females aged I8 years and over and "Girls" to those under I8; "Men" refers to males aged 2I years and over and

"Boys" to those under 2I. 
age and gender wage differentials and employment distributions. One major strand of labour market segmentation theory - Dual Labour Market (DLM) theory - provides a useful starting point for the analysis of variations in workforce composition. This argues that the labour market can be divided into "primary" and "secondary" sectors. The primary sector is characterized by high wages and fringe benefits, skilled jobs, training and promotion opportunities, and employment stability. Conversely the secondary market is distinguished by low wages and fringe benefits, lack of skill or opportunities for promotion or training, labour-intensive production, and unstable employment. The primary market is dominated by white adult males, while in the secondary market, females, young workers, and ethnic minorities are overrepresented. ${ }^{\text {II }}$

Primary labour markets are created by employers in order to minimize the turnover of workers on whom a premium is placed, as they embody enterprise-specific skills (skills specific to the particular firm, rather than being more generally available) and associated on-the-job training. "Technological specificity" is one important type of enterprise-specific skill. This involves the entire set of tasks which comprise a work process and imparts specificity to skill mainly through the speed and accuracy with which these are executed. ${ }^{\mathrm{I2}}$ Technological specificity is likely to be of particular importance for capital-intensive industries, where the speed with which expensive machinery is worked will have the greatest impact on overall costs. Workers in such industries are often paid above market rates in order to secure a workforce who can ensure high rates of throughput for expensive machinery. High-wage policies consistent with such production strategies were adopted by a number of major interwar manufacturers that used highly mechanized production techniques, most notably some UK branches of American multinationals, such as Ford, Shredded Wheat, and Kodak. ${ }^{13}$

Conversely, secondary sector jobs "are, above all, jobs in which there is a low investment in human capital" ${ }^{14}$ Barron and Norris identify five main attributes that make a particular social group a likely source of secondary workers: dispensability; clearly visible social difference; little interest in acquiring training; low economism; ${ }^{15}$ and lack of solidarity. ${ }^{16}$ Dispensability is defined as the ease with which an employee can be removed from a

II. Peter B. Doeringer and Michael J. Piore, Internal Labour Markets and Manpower Analysis (Lexington, MA, 197I); Peter Sloane, "The Structure of Labour Markets and Low Pay for Women", in Peter Sloane (ed.), Women and Low Pay (London, 1980), pp. I27-164.

I2. Doeringer and Piore, Internal Labour Markets, p. I6.

13. John H. Dunning, American Investment in British Manufacturing Industry (London, 1958), p. 255 .

I4. R.D. Barron and G.M. Norris, "Sexual Divisions and the Dual Labour Market", in Diana L. Barker and Sheila Allen (eds), Dependence and Exploitation in Work and Marriage (London, 1976), p. 60 .

15. Defined as the relative importance a worker places on monetary rewards.

I6. Barron and Norris, "Sexual Divisions", p. 53. 
redundant job. An important component is high voluntary turnover characteristic of women, "mavericks" (chronic job-changers), and youths. As women and youths were perceived as a barrier to unionization during this period, high employment of such workers also facilitated dispensability through involuntary redundancies. ${ }^{17}$

Milkman has offered an explanation of sex-typing in interwar American industry with strong similarities to DLM theory. Taking the examples of the motor vehicle and electrical goods industries, she argues that the much higher proportion of female employees in electrical goods was due to the labour-intensive and deskilled nature of production and the consequent reliance of management on elaborate piecework systems, facilitating female and juvenile employment. In motor vehicles, by contrast, production was very capital-intensive and employers used high wages to retain a workforce sufficiently reliable to maintain production at the pace determined by the moving assembly line ${ }^{{ }^{8}}{ }^{2}$ Savage has argued that British employment practices mirrored those found by Milkman in America. ${ }^{19}$ If this is correct, there should be a strong relationship between the percentage of adult male workers employed by each industry and its fixed capital per worker.

While there are no published data on fixed capital per worker, analysis of the available proxies by Florence concluded that horsepower per worker despite being an imperfect measure of capital - is the best available, agreeing tolerably with other less easily obtainable measures. ${ }^{20}$ Figure I examines the relationship between the proportion of adult men employed in twenty-nine industrial subdivisions covered in the 1935 survey, and their average horsepower per worker, according to Florence's (1930) data. ${ }^{2 \mathrm{I}}$ This shows a strong correlation between capital intensity and the proportion of men employed, as is confirmed by regression analysis. ${ }^{22}$ Thus it appears that, at sectoral level, there was a clear relationship between capital intensity and the allocation of jobs between adult male and cheaper workers. In order to further examine the factors governing workforce selection and composition, it is necessary

17. See, for example, Sheila Lewenhak, Women and Trade Unions (London, 1977), pp. I86-210; Glucksmann, Women Assemble, p. 193; Sylvia Walby, "Spatial and Historical Variations in Women's Unemployment and Employment", in Lancaster Regionalism Group, Localities, Class, and Gender (London, 1985), pp. 161-176; Gail Braybon, Women Workers in the First World War: The British Experience (London, 1981).

18. Milkman, "Female Factory Labor".

19. Savage, "Trade Unionism", pp. 217-218.

20. P. Sargant Florence, Investment, Location, and Size of Plant (Cambridge, 1948), pp. 90-Ioo.

2I. The sample excluded particularly heavy industries, in which the heavy nature of the work was an important factor excluding women and juveniles from many jobs.

22. $\%$ Men $=22.922+13.080$ horsepower per worker

$$
(6.234)^{*}(7.768)^{*}
$$

$\mathrm{R}^{2}=0.69 \mathrm{I} \quad \mathrm{N}=29$ F-statistic $=60.338$

(t-values are in parentheses.)

* Significant at the I per cent confidence interval. 


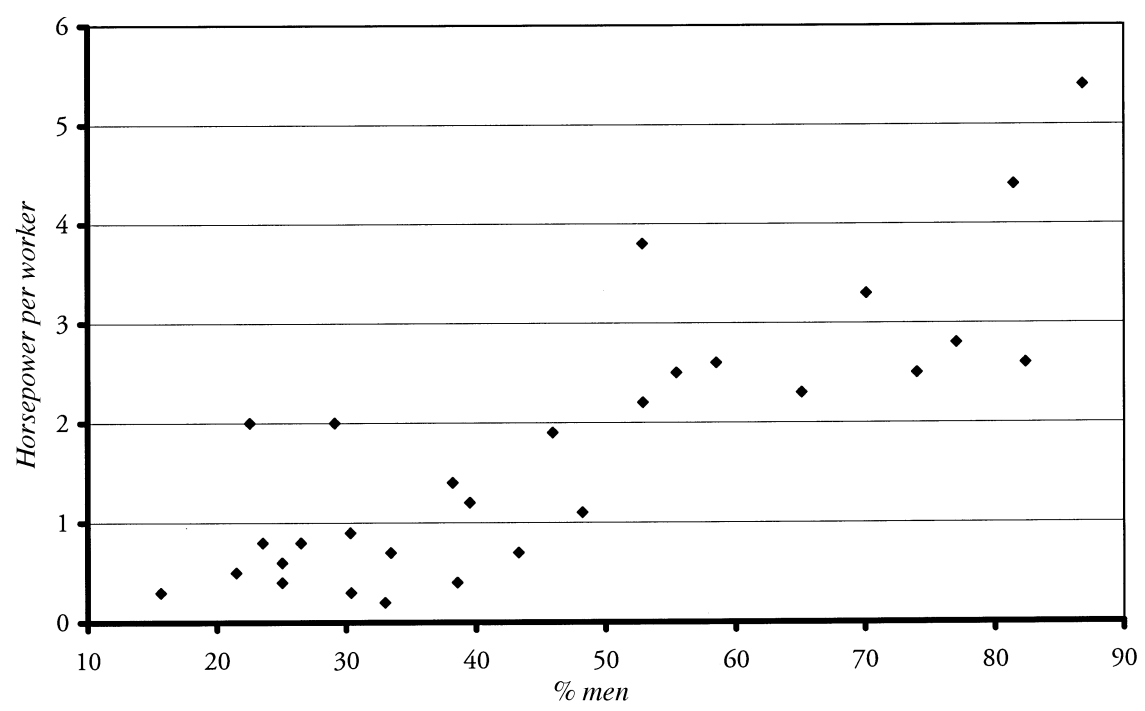

Figure I. The relationship between adult male employment (1935) and horsepower per worker (1930) for 29 British industrial subdivisions.

Sources: Employment: as for Table I; horsepower: P. Sargant Florence, Investment, Location, and Size of Plant (Cambridge, 1948), Appendix 4.

to explore employment practices at a less aggregate level. The following section therefore examines the local labour markets in eight rapidly growing industrial centres, dominated by assembly and other light industries.

\section{NEW INDUSTRIAL COMMUNITIES}

As Massey has noted, major changes in the labour process have important implications for the location of industry. Even if these involve no "real" deskilling, they may enable jobs to be formally downgraded, often through the employment of a new workforce with a weaker negotiating position. New industrial locations are determined by the interaction between these labour requirements and the geography of an area's previous industrial inheritance, in conjunction with other factors such as proximity to markets, power, or materials, and the organizational structure of capital. ${ }^{23}$ During the interwar period, the London conurbation (and, to a lesser extent, the West Midlands) proved attractive to manufacturers in the expanding industries on account of its strong market links for both producer and consumer goods, together with its inherited industrial base of diversified light industries and associated services. Meanwhile, in contrast to the "locational 
hierarchy spatial structure" of manufacturing which emerged in postwar Britain, the organizational structure of most firms was not sufficiently developed for them to split production between a number of plants located in different areas. Instead the characteristic firm conducted all its manufacturing and administrative activities from a single plant which had to be suitably located for all these functions. ${ }^{24}$

The areas which proved most attractive to the new assembly industries, and which therefore experienced the most rapid industrial growth, were generally small/medium towns on the fringes of London, or larger communities around the West Midlands. Table 2 provides examples of eight such centres, case studies for which inform this article. Six lie on the outskirts of the London conurbation, the seventh, Coventry, was the most rapid growth centre of the West Midlands and the final centre, Oxford, also had important links with the West Midlands. The eight centres were dominated by expanding industries, especially the sectors which achieved the most rapid national growth - motor vehicles, electrical and mechanical engineering, metal goods, and printing and paper. These sectors collectively increased their national workforce (employed and unemployed) by 557,920 people between 1923 and 1938 , equivalent to around 96 per cent of the total net increase in the insured manufacturing workforce.

The six centres close to London have a number of important features in common. The attraction of firms decentralizing from London and/or overseas multinationals proved key to their growth, ${ }^{25}$ while in each centre a promoting authority had played a leading role in attracting these firms. At Luton and Watford the role of promoter had been taken by new industry committees formed by their local councils and business communities prior to the First World War; ${ }^{26}$ in Letchworth and Welwyn it was played by the garden city companies that developed these towns and their industrial estates; while in Slough and Dagenham it was filled by industrial estate development companies. ${ }^{27}$ These promoting agencies also provided factories

24. Carol E. Heim, "Industrial Organization and Regional Development in Interwar Britain", Journal of Economic History, 43 (1983), pp. 931-952.

25. P. Power, "Hertfordshire Local Survey Report", January 1943, Nuffield College, Oxford, Nuffield College Social Reconstruction Survey Archive [hereafter NCSRS], CI/58 (Part I); W.G. Holford, "The Location and Design of Trading Estates", Journal of the Town Planning Institute (March 1939), p. I54; "Welwyn Garden City: Some Aspects of its Economic History", Ministry of Town and Country Planning, New Towns Research Section, June 1950 [hereafter, MTCP, Welwyn Report], Public Record Office, Kew [hereafter, PRO], HLG9o/44O; UK Parliament, Royal Commission on the Geographical Distribution of the Industrial Population, Minutes of Evidence (London, 1940), p. 342.

26. Stephen Bunker, "A Small Town Outside Vauxhall: Luton in the Twentieth Century", unpublished paper, 1993; W. Francis Goodrich, Watford: Its Advantages as an Industrial and Residential Centre (Watford, c. 1908), pp. I0, I2.

27. Prior to the arrival of Ford at Dagenham, and the establishment of the Ford industrial estate there, Dagenham's industrial development had been dominated by the literage company Samuel Williams \& Sons Ltd, which had launched an industrial estate there from I9o9 (including the 
Table 2. The case-study industrial centres

\begin{tabular}{|c|c|c|c|}
\hline Centre & Population 1921 & Population 1939 & Main industries \\
\hline Letchworth & 10,313 & $17,400^{\mathrm{a}}$ & $\begin{array}{l}\text { Engineering, clothing, vehicles, } \\
\text { printing, metal industries, } \\
\text { furniture, scientific instruments }\end{array}$ \\
\hline Welwyn & $430^{\mathrm{b}}$ & 14,100 & $\begin{array}{l}\text { Metal industries, chemicals, } \\
\text { electrical engineering }\end{array}$ \\
\hline Dagenham & 9,127 & 109,300 & $\begin{array}{l}\text { Motor vehicles, electrical } \\
\text { engineering }\end{array}$ \\
\hline Oxford & $67,290^{c}$ & $96,350^{\mathrm{d}}$ & Motor vehicles, printing \\
\hline Watford & 45,910 & 66,520 & $\begin{array}{l}\text { Printing and paper, food and } \\
\text { drink, electrical engineering, } \\
\text { motor vehicles }\end{array}$ \\
\hline Slough & 16,000 & $60,000^{\mathrm{e}}$ & $\begin{array}{l}\text { Motor vehicles, food and drink, } \\
\text { electrical engineering, chemicals, } \\
\text { musical instruments }\end{array}$ \\
\hline Coventry & 128,152 & 224,267 & $\begin{array}{l}\text { Motor vehicles and cycles, metal } \\
\text { goods, electrical engineering, } \\
\text { mechanical engineering, rayon }\end{array}$ \\
\hline Luton & 57,075 & 94,110 & $\begin{array}{l}\text { Motor vehicles, engineering, } \\
\text { hats }\end{array}$ \\
\hline
\end{tabular}

Sources: MTCP, Welwyn Report; Tyrewhitt, Welwyn survey; NCSRS, I/II2, report on Greater London (Part I), April I943; NCSRS, CI/58 (Part I), Hertfordshire Local Survey report, January 1943; Watford Civic Survey, vol. 3; Margaret M. Attlee, Mobility of Labour (Oxford, I944), p. 35; Bill Lancaster, "Whose a Real Coventry Kid? Migration into Twentieth Century Coventry", in Bill Lancaster and Tony Mason (eds), Life and Labour in a Twentieth Century City: The Experience of Coventry (Coventry, 1986), pp. 57-80, 67; A. Shenfield and P. Sargant Florence, "Labour for the War Industries: the Experience of Coventry", Review of Economic Studies, I2 (1944-1945), pp. 3I-46; Fred Grundy and Richard Morris Titmuss, Report on Luton (Luton, I945); D. Ian Scargill, "Responses to Growth in Modern Oxford", in R. C. Whiting (ed.), Oxford: Studies in the History of a University Town since I80o (Manchester, I993), pp. IIO-I30; UK Parliament, Royal Commission on the Distribution of the Industrial Population, Report (Cmd 6153 of 1940), p. 280; C.B. Purdom, The Letchworth Achievement (London, 1963), p. II3.

Notes: ${ }^{a}$ end of $1938 ;{ }^{b}$ I920; ${ }^{c}$ includes area covered by a 1929 boundary extension; ${ }^{\mathrm{d}}$ I937; ${ }^{\text {e }}$ 1938. NB: late I930s population figures are estimates.

and/or sites for incoming firms, or assistance with acquiring sites (sometimes in combination with other inducements).

The remaining centres, Coventry and Oxford, developed their new industries along more evolutionary lines. Coventry had made a successful transition from a ribbon and watchmaking industrial base of artisan workshops to cycle and, later, motor vehicle manufacture, initially using the same artisan producers. Small scale was initially compensated for by extensive sub- 
contracting and components purchases from Birmingham and the Black Country, before the more successful firms moved to factory production. ${ }^{28}$ Oxford's motor industry similarly developed from much smaller-scale activity in the cycle trade, initially relying on extensive components purchases from West Midlands' suppliers. ${ }^{29}$

The "new" character of these areas (as centres for their principal interwar industries) appears to have been an important attraction to industrialists. There is strong evidence that manufacturers deliberately located in new industrial areas, partly to escape the greater strength of organized labour in more established centres. A 1932 Whitehall review of factors determining the location of overseas multinationals noted a widely-held belief that strong, inflexible, unions in the older industrial areas would hamper their development of new industries..$^{30}$ Similarly, Dennison found that collective wage agreements and union activity had a discernable influence in diverting industry to new areas. ${ }^{3 \mathrm{I}}$ This also had a gender and age dimension; feminist analysis has drawn attention to the weakness of trade unions (acting as patriarchal forces that might exclude women from employment) as a factor behind rising female employment in the new industrial areas. ${ }^{32}$ Meanwhile the cheapness and flexibility of such labour (together with other forms of nonunionized labour) was, in turn, an important attraction to industrialists, who located in such areas partly to escape restrictions on its use.

Marx, who argued that the subsitution of adult male labour by females and juveniles was a key feature of mechanization, ${ }^{33}$ noted that, in addition to lowering labour costs, their employment constituted a means of reducing the opposition of organized labour to mechanization. "By the excessive addition of women and children to the ranks of the workers, machinery at last breaks down the resistance which the male operatives in the manufacturing period continued to oppose to the despotism of capital. ${ }^{34}$ This process was evident during the interwar years, as a result of changes in manufacturing technology and the organization of production which greatly increased the proportion of jobs involving relatively simple, repetitive, tasks. In I93I the New Survey of London Life and Labour [hereafter New Survey] noted that, "The great development in the use of machine tools in the engineering and metal trades has been accompanied [...] by the growth of a class of

28. P.W. Carr, "Engineering Workers and the Rise of Labour in Coventry, 1914-I939", (Ph.D., University of Warwick, 1978), ch. I.

29. P.W.S. Andrews and Elizabeth Brunner, The Life of Lord Nuffield (Oxford, 1955).

30. PRO, BT56/40/CIAr80o/7I.

3I. S.R. Dennison, The Location of Industry and the Depressed Areas (London, 1939), p. 80.

32. Walby, "Spatial and Historical Variations", p. 169.

33. Karl Marx, Capital, vol. I (London, 1954), p. 372.

34. Ibid., p. 379. 
machine operators, intermediate between the skilled craftsman and the unskilled labourer in status, earnings, and specialized ability." ${ }^{35}$

"New" industries, such as electrical engineering and motor vehicles, involved a high proportion of assembly and other un/semiskilled operations. Meanwhile, traditional industries such as shoe manufacture and hosiery also experienced deskilling as a result of new technology, leading to a substantial growth in female and juvenile employment and the establishment of new production centres in areas where unions had insufficient strength to resist deskilling. ${ }^{36} \mathrm{New}$, mass production, technology thus offered an incentive to employ female, juvenile, and other weakly-unionized labour, in order to prevent unions resisting its introduction or opposing restrictions on its use, while simultaneously reducing the value of skills possessed by workers trained in older techniques. Both effects made new industrial centres preferable to their long-established counterparts from the viewpoint of manufacturers.

Flexibility and low industrial militancy were desired characteristics common to both primary and secondary sectors of the new manufacturing workforce. Some manufacturers, in industries such as motor vehicles where capital-intensive production required high throughput to keep costs down - also placed a considerable premium on a reliable, stable, highly productive workforce, evolving employment strategies characteristic of primary labour markets. These typically used machine pacing and tight worker supervision, and were prepared to pay high time wages to retain reliable staff. Their ideal workforce consisted of adult male workers - on account of their low voluntary labour turnover - drawn from sectors such as agriculture, that were perceived to be relatively free of industrial militancy or entrenched attitudes regarding working practices. Meanwhile other manufacturers, in labour-intensive sectors such as electrical engineering, faced much lower fixed capital costs and thus aimed to minimize their greatest costs - wages - by drawing on cheaper workers. These evolved strategies characteristic of secondary labour markets, employing a large proportion of women, juveniles and - when such workers were in short supply - internal migrants, and often using piecerate systems to motivate output and link wages directly to productivity. The new industrial workforce in both capital and labour intensive sectors was thus drawn from a "reserve army" of workers, whose composition was determined by the multiple dimensions of age, gender, occupational background, and geographical mobility, as outlined below.

35. London School of Economics [hereafter, LSE], The New Survey of London Life and Labour, vol. 2: London Industries I (London, 193I), p. 7.

36. Alan Fox, The History of the National Union of Boot and Shoe Operatives 1874-1957 (Oxford, 1958), pp. 484-485; Richard Gurnham, A History of the Trade Union Movement in the Hosiery and Knitwear Industry, 1776-1976 (Leicester, 1976), pp. 105-106. 


\section{THE GENDER DIMENSION}

Glucksmann has argued that, during the interwar period, women became "the central labour force engaged in direct assembly work [...]. In direct production, all women were engaged in assembly work and, with the exception of car assembly, only women were assemblers". ${ }^{37}$ Thus, "Since all women were allocated to semiskilled production work and men to everything else, including all servicing, the division between direct and indirect producers was effectively constituted as a division between women and men." 38

Employment statistics reveal that Glucksmann greatly overemphasizes the importance of women in direct production. The proportion of women aged over sixteen in the insured labour force rose slightly, from 26.I to 26.6 per cent from 1923-1927, while the proportion aged sixteen to sixty-four experienced a further slight rise, from 27.2 to 27.7 per cent, from 19271939. ${ }^{39}$ This relative stability was largely due to the decline of the textile industry (traditionally by far the most important industrial employer of women), together with the growth of female employment in other sectors. From 1923-1937 the number of female insured workers (employed and unemployed $)^{40}$ rose by 68.7 per cent in vehicle construction and repair, 64.2 per cent in the metal industries, and 62.5 per cent in engineering. ${ }^{41}$ However, much of this increase was accounted for by the general employment growth of these sectors, the proportion of women employed in vehicles and metal industries showing only modest increases. As Table 3 demonstrates, the only sectors with over 50 per cent female employment in 1939 were those where women already formed more than half the insured workforce in 1923, and none of these are usually characterized as major assembly industries.

Analysis by Leser, based on the 193I Census, indicates that the proportion of females in the occupied population was highest in the textile-dominated northwest (4I.9 per cent) and in London and the southeast (39.9 per cent). The Midlands, Scotland, and Yorkshire followed, with the more agricultural regions below them, and finally the coal-based northern region and Wales, with rates of less than 25 per cent. ${ }^{42}$ The 193I Census indicates that the case study centres had female employment ratios below the average for their regions. ${ }^{43}$ Female employment in these centres may be underestimated by

37. Glucksmann, Women Assemble, p. 3.

38. Ibid., p. 203.

39. C.E.V. Leser, "Men and Women in Industry", Economic Journal, 42 (1952), pp. 326-344, 327.

40. Aged sixteen and over in 1923 and sixteen to sixty-four in 1937.

4I. Glucksmann, Women Assemble, pp. 48-49.

42. For workers aged fourteen and over, including those unemployed. Leser, "Men and Women", p. 339 .

43. UK Parliament, Census of England and Wales, I93I, Occupation Tables (London, 1934), Tables I6 and 17; A. Shenfield and P. Sargant Florence, "Labour for the War Industries: the Experience of Coventry", Review of Economic Studies, I2 (1944-I945), pp. 3I-49, 34. 
Table 3. Women as a proportion of insured employees, 1923 and 1939

\begin{tabular}{l|c|c}
\hline Sector & $1923^{*}$ & $1939^{* *}$ \\
\hline Clothing & 65.0 & 70.2 \\
Textiles & 60.3 & 61.3 \\
Pottery, earthenware, etc. & 50.5 & 56.3 \\
Food, drink, tobacco & 40.5 & 42.3 \\
Paper, printing & 38.8 & 38.7 \\
Miscellaneous & 31.7 & 38.9 \\
Miscellaneous metal industries & 30.1 & 32.0 \\
Leather & 29.9 & 37.7 \\
Chemicals & 25.2 & 26.7 \\
Woodworking & 15.6 & 15.6 \\
Glass & 15.1 & 19.7 \\
Bricks, tiles, etc. & 12.2 & 6.3 \\
Vehicles & 8.6 & 8.9 \\
Engineering & 6.5 & 10.3 \\
Metal manufacture & 5.1 & 5.6 \\
Non-metallic mineral products & 3.6 & 5.1 \\
Shipbuilding & 1.5 & 1.8 \\
\hline
\end{tabular}

Source: C.E.V. Leser, "Men and Women in Industry", Economic Journal, 42 (1952), pp. 326-344, 330.

Notes: * Aged I6 and over ${ }^{* *}$ Aged I6-64

the Census, as it appears that women and girls formed a relatively large proportion of workers commuting from surrounding villages. However, estimates of the composition of the workforce - rather than working population - at Slough and Welwyn, indicate that, while such underestimation did occur, women workers were still underrepresented. ${ }^{44}$ This was probably largely due to these centres' industrial composition, dominated by those industries which achieved the largest national employment growth - motor vehicles, electrical engineering, mechanical engineering and metal goods. These were sectors in which the proportion of female employment was generally below average, but rose significantly over the interwar period. Female employment as such formed a significant and growing, but hardly dominant, component of their labour markets. The lower geographical mobility of women may also have been an important influence, as these towns experienced considerable long-distance in-migration.

Female workers tended to be employed on repetitive, labour-intensive, un/semiskilled processes. Within particular factories, there were usually very strong demarcation lines between men's and women's work. However, segregation was sometimes less clear-cut between factories. As a 1929 official study noted, in a diverse group of industries certain processes were

44. Savage, "Trade Unionism"; W. Davies, "The Nature and Significance of Trading Estates with Special Reference to the Treforest and Slough Estates" (M.A., University Of Wales, 1951), p. I38; Tyrewhitt, Welwyn Survey; MTCP, Welwyn Report. 
conducted by men in one factory and women, or in some cases boys, in another. ${ }^{45}$ The demarcation of particular jobs as "women's work" accords well with DLM theory, which highlights women's high "voluntary" labour turnover as a key feature of their concentration in secondary labour markets. As the 1929 study argued, the expected termination of work on marriage encouraged women's employment in un/semiskilled jobs:

The industrial life of women is, in general, a short one. This makes them unwilling to spend much time on [...] training and disposes them to seek occupations where they can earn a good wage as quickly as possible. For the same reason, managers are unwilling to train up workers for skilled occupations if they are likely to lose them when they have become really useful. ${ }^{46}$

In I92I and I93I sixty-nine per cent of working women were under thirtyfive, as women generally left full-time paid work on marriage - though this varied greatly according to location and industry. ${ }^{47}$ The proportion of working women who were married varied from twenty-eight per cent for weavers to only five per cent in electrical apparatus manufacture and seven per cent for sugar confectionary, scientific instruments, printing, and photography. ${ }^{48}$ Tradition played a pivotal role regarding geographical patterns; some centres such as the Lancashire cotton textile districts, or Luton, had a tradition of married women's employment which became reflected in the new industries that settled there. ${ }^{49}$ In many other areas women rarely continued in work after marriage, social pressure being reinforced by employers' formal or informal marriage bars.

Many employers justified marriage bars on moral grounds, though even at Rowntrees, where the owners' Quaker values moulded labour policy, the firm's rigid marriage bar was temporarily relaxed when shortages of suitable labour made this necessary. ${ }^{50}$ Marriage bars in fact had an important economic rationale. At firms like Courtaulds, which recruited girls at fourteen, they were part of a wider policy of fostering a "respectable" atmosphere which made it more socially acceptable for families to send girls into factory work. More importantly, marriage bars fostered dispensability, providing a relatively uncontroversial means of dismissing older females, and thus keep-

45. UK Parliament, A Study of the Factors Which Have Operated in the Past and Those Which Are Operating Now to Determine the Distribution of Women in Industry, Cmd 3508 of 1930 [presented to Parliament in 1929].

46. UK Parliament, Study of the Factors, p. 29.

47. Catherine Hakim, Occupational Segregation: A Comparative Study of the Degree and Pattern of the Differentiation Between Men and Women's Work in Britain, the United States and Other Countries, Dept. of Employment Research Paper No. 9. (London, 1979), p. Io.

48. UK Parliament, Study of the Factors, p. 33.

49. Bunker, "Small Town Outside Vauxhall".

50. Robert Fitzgerald, Rowntree and the Marketing Revolution, I862-1969 (Cambridge, 1995), p. 238 . 
ing the average age of women workers, and their strongly age-related wages, low. ${ }^{\text {SI }}$ In $193 \mathrm{I}$ the labour force participation rate for women aged fourteen to twenty-four was sixty-nine per cent; for those aged twenty-five to thirtyfour it fell to only thirty-six per cent on account of marriage (single women's participation rates were seventy-six and eighty-one per cent respectively). ${ }^{52}$ By taking older women out of the workforce as they married (typically at around age twenty), the marriage bar allowed Courtaulds to maintain the proportion of juveniles in their female workforce at a constant one third over the interwar period. ${ }^{53}$

As Beechey has noted, Marx's argument that employers use female and juvenile workers to weaken the resistance of organized labour to mechanization implies that such tactics will produce union opposition to their employment. ${ }^{54}$ Women's employment was seen as a threat by unions, as many processes offered considerable scope for the replacement of male by female labour, especially when changes in technology or the organization of production allowed reclassification in terms of skill and gender. The New Survey noted that in industries where male and female labour "is largely employed side by side" male unemployment was substantially higher than that for women (almost twice as high in the engineering trades and even greater in the boot and shoe industry and tailoring). 55 Such competition also had a generational component; adults of both sexes experienced higher unemployment than juveniles. $^{56}$

Unions vigorously resisted the extension of female employment into sectors where women might compete with adult males. Such activity has been highlighted in some feminist analysis as having played a central role in structuring occupations into "men's work" and "women's work". ${ }^{57}$ The unions' success varied geographically according to local union strength and labour market conditions, producing the phenomenon, noted above, of certain processes being done almost exclusively by men in one area and women in another. ${ }^{58}$ Variations over time in labour market conditions could also influence the gender allocation of jobs. For example at Rowntrees the onset of depression from 1929 enabled the firm to gain union compliance for a

5I. UK Parliament, Study of the Factors, p. 24.

52. Hakim, Occupational Segregation, pp. 6-7.

53. Josie Castle, "Factory Work for Women: Courtaulds and GEC Between the Wars", in Bill Lancaster and Tony Mason (eds), Life and Labour in a Twentieth Century City: The Experience of Coventry (Coventry, 1986), pp. I44-I47.

54. Veronica Beechey, "Some Notes on Female Wage Labour in Capitalist Production", Capital and Class, 3 (1977), pp. 45-66, 55 .

55. LSE, New Survey of London Life and Labour, vol. 2, pp. 20-2I.

56. Ibid., p. 36.

57. Linda Murgatroyd, "Occupational Stratification and Gender", in Lancaster Regionalism Group, Localities, Class, and Gender, pp. I2I-I44.

58. UK Parliament, Study of the Factors, pp. 9-IO. 
policy of substituting female or juvenile workers for men on some processes. $^{59}$

\section{THE AGE DIMENSION}

The division of labour, and employment competition, between men and women was overlaid by the relationship between adult and juvenile employment. The key role of age as a dimension of labour market segmentation and employment competition during this period has often been neglected by writers who have examined the past primarily as a means of explaining current disparities in employment patterns and opportunities. Juveniles formed a significant sector of the interwar labour market, with most children leaving school at the age of fourteen. As noted above, both boys and girls were paid wages well below those for adult women, and thus constituted a preferred source of labour for processes where there was little productivity loss from their employment or where labour-intensive production and piecerates made their employment more profitable, despite lower productivity. While recorded unemployment in Britain averaged almost fourteen per cent from 1920-1938, juvenile unemployment averaged only five per cent. There may be some underrecording of juvenile unemployment, particularly with regard to those under sixteen, for whom registration was voluntary prior to $1934{ }^{60}$ However, comparison of the Insurance Office data with the Census estimate for 193I indicates no significant underestimation. ${ }^{61}$

As Table I (p. 452) shows, in 1935 the employment of "juveniles" in manufacturing was almost as great as that of women (though applying age cutoffs at eighteen for girls and twenty-one for boys distorts the comparison). Juveniles constituted a particularly important segment of the female workforce; girls aged fourteen to seventeen comprised only 9.I per cent of the British female population aged fourteen to sixty-four in 193I, but made up over one-quarter of the female workforce in 1935 for every sector in Table I (with the exception of textiles). An investigation of particular firms, conducted by Dennison in the late I930s, revealed a preference for engaging juveniles. Employers believed that they could be more easily trained; indeed the specialized skills of older workers were often regarded as a disadvantage. Dennison also found, using aggregate statistical evidence, that the proportion of juveniles was considerably higher in expanding than in declining sectors. ${ }^{62}$

Evidence from the case-study centres indicates that juveniles were

59. Fitzgerald, Rowntree, pp. 274-29I.

6o. W.R. Garside, "Juvenile Unemployment Between the Wars: a Rejoinder", Economic History Review, 2nd series, 32 (1979), pp. 529-532.

6r. Daniel K. Benjamin, and Levis A. Kochin, "What Went Right with Juvenile Unemployment Policy Between the Wars: A Comment", ibid., pp. 523-528.

62. Dennison, Location of Industry, p. 78. 
underrepresented in their workforces, as in-migrants made up a large proportion of their working populations and younger juveniles had low geographical mobility. This produced local shortages of juvenile labour, girls and younger boys having very low unemployment rates. For example, in the Watford area men aged over twenty-one and those aged eighteen to twenty had unemployment rates of 6.4 and 7.0 per cent in September 1933, while boys under eighteen had recorded unemployment of only 0.6 per cent. Meanwhile unemployment rates for females aged over twenty-one, aged eighteen to twenty, and under eighteen, were I.9 per cent, 0.4 per cent and 0.3 per cent respectively. ${ }^{63}$ The Welwyn survey reported very low unemployment rates for juvenile females and males under sixteen. While male unemployment increased sharply after age sixteen, female unemployment remained very low until age twenty-one, but then rose from an average of 0.8 per cent for ages eighteen to twenty-one to 4.8 per cent for women over twenty-one. Some Welwyn firms laid great stress on difficulties in obtaining sufficient young (fourteen- to sixteen-year-old) girls - a sector of the population with particularly low geographical mobility. ${ }^{64}$

Similar results were obtained in Hatton and Bailey's analysis of the New Survey juvenile unemployment data. They found that unemployment for males aged sixteen to twenty-one rose sharply and continuously with age, the unemployment rate for twenty-one-year-olds being almost three times that for those aged sixteen. ${ }^{65}$ Meanwhile there was no similar increase for juvenile females. The absence of increased unemployment for older female juveniles was probably largely due to the fact that girls' wages rose much less sharply with age than was the case for boys, culminating in wide gender wage differentials for adults.

The demand for juvenile labour was partly for juveniles per se. The Ministry of Labour noted that there was little demand for juvenile (especially boy) "transferees" - government-assisted internal migrants - aged seventeen to eighteen (relative to younger juveniles), despite these often having more years of school education, as few juvenile jobs were available that would enable them to become self-supporting on reaching eighteen (i.e. jobs leading to adult employment). ${ }^{66}$ Many juveniles were employed in "blind alley" jobs and dismissal at ages eighteen to twenty-one was said to be common for boys. ${ }^{67}$ Such workers, having learned no skill of sufficient value to com-

63. Watford Civic Survey, vol. 2. Unemployment data for August 1932 reveal similar age/gender differentials.

64. Tyrewhitt, Welwyn Survey.

65. Timothy J. Hatton and Roy E. Bailey, "Unemployment Incidence in Interwar London", unpublished paper, 1998.

66. UK Parliament, Ministry of Labour, Report for the Year 1936 (P.P. 1936-1937, I2), p. 42; Report for the Year 1938 (P.P. I938-1939, 12), p. 43.

67. John Gollan, Youth in British Industry (London, 1937); G. Mikoleit, "Industrial Restructuring and Women's Employment: the Case of the Food Industry in Inter-war Britain” (M.Phil., Polytechnic of the South Bank, I986), pp. I00-IOI. 
pensate for their age, were largely relegated to "dead-end" secondary labour market jobs. ${ }^{68}$ In some expanding industrial centres with significant unionization, such as Coventry, juvenile males were particularly valued by employers, as they fell outside the scope of local collective wage negotiations and their employment, followed by dismissal at age twenty-one, constituted an important means of counteracting union wage pressure. ${ }^{69}$ This job competition led unions to oppose juvenile employment on many processes (especially outside regulated apprenticeships). According to a I937 study by Gollan, a growing number of small-scale strikes were occurring in the engineering trades against piecemeal attempts to introduce boys on machines previously operated by skilled men. ${ }^{70}$

\section{THE LOCAL DIMENSION}

While it is generally true that employers in the new industries rejected established industrial workers in favour of those drawn from outside manufacturing, in some areas workers made redundant from declining local industries did constitute a significant source of labour for new firms. For example rayon plants became concentrated in areas such as Coventry and Lancashire, where (in addition to other factors) appropriate labour was available from declining textile industries. ${ }^{71}$ In Luton the straw hat trade provided an important source of labour for its new industries, ${ }^{72}$ while Birmingham's electrical components industry drew large quantities of workers from its declining jewellery quarter. ${ }^{73}$ These cases all involve supplies of predominantly female workers, suggesting that these were much easier to redeploy to new industries than their male counterparts (probably largely due to their lower wages and weaker unionization). Another local source of workers were domestic servants (especially important in affluent areas with large servant communities). In Oxford many younger college servants turned to better paid work in the local motor vehicle industry. ${ }^{74}$ Similarly, many domestic servants in London and the southeast turned to manufacturing, domestic service being regarded as a residual occupation which most women would only consider when factory employment was unavailable. ${ }^{75}$

68. Gollan, Youth, pp. I84-190; Carr, "Engineering Workers", p. 438.

69. Carr, "Engineering Workers", p. 438.

70. Gollan, Youth, p. 67.

7I. J. Harrap, "Rayon", in Neil K. Buxton and Derek H. Aldcroft (eds), British Industry Between the Wars (London, 1979), pp. 276-302.

72. Fred Grundy and Richard Morris Titmuss, Report on Luton (Luton, 1945), p. 25.

73. Michael Beesley, "Changing Industrial Advantages in the British Motor Car Industry", Journal of Industrial Economics, 6 (1957), pp. 47-57.

74. D. Ian Scargill, "Responses to Growth in Modern Oxford", in R.C. Whiting (ed.), Oxford: Studies in the History of a University Town since I800 (Manchester, I993), pp. IIO-I3O, III.

75. LSE, New Survey of London Life and Labour, vol. 2, p. 429; Glucksmann, Women Assemble, pp. $247-248$. 
A further local source of workers was agricultural labourers, together with their female and juvenile relatives. National employment in agriculture and forestry declined from an average of $1,004,000$ in $1920-1922$ to 735,000 in 1937-1938. The heaviest falls were experienced by males under twenty-one, whose numbers declined by forty-four per cent between I92I-I924 and 1938. ${ }^{76}$ Workers were drawn from agriculture by higher manufacturing wages; for example wages for adult male agricultural workers in the Watford area were around two-thirds, or less, of those for factory workers. ${ }^{77}$ High wage differentials proved a considerable incentive; the migration of farm labourers to Ipswich and other East Anglian towns was so substantial during the I930s that it eventually produced a shortage of agricultural workers in the region. ${ }^{78}$ Male farm workers were particularly sought after by manufacturers in capital-intensive "primary" labour markets, such as motor vehicles, as they were viewed as being flexible, reliable, and nonunionized. For example Oxford's motor industry relied heavily (especially during its early development) on workers from surrounding rural districts. According to an estimate by Whiting, by 1936 there were around 3,000 ex-agricultural workers in the Cowley motor industry (compared to 1,266 long-distance migrants from Wales, the north, and Scotland). ${ }^{79}$

Locally-recruited adult male workers, such as former agricultural labourers and Oxford's college servants, shared the characteristics of low previous wages, weak (if any) unionization, and nonindustrial backgrounds. As such, they formed part of what Marx termed the latent reserve army of labour workers attracted from nonindustrial sectors offering inferior pay and conditions. While more expensive than women or juveniles, such workers were of particular attraction to employers in primary sectors, such as motor vehicles, as they were seen as being reliable, disciplined, and willing to accept the working conditions set by employers.

Meanwhile women and juveniles in agricultural areas surrounding industrial communities were particularly attractive to employers in secondary labour markets, on account of their low transfer wages from rural work. In Letchworth thirty to forty per cent of factory workers in 1935 were said to be young people who commuted in daily from surrounding villages. ${ }^{80}$ Welwyn's factories relied extensively on rural commuters, especially girls some twenty-eight per cent of its workforce living two to twenty miles away,

76. Sidney Pollard, The Development of the British Economy 19I4-I99o (London, 1992), p. 66.

77. Watford Civic Survey, vols 2 and 3.

78. E.D. Smithies, "The Contrast between North and South in England 1918-1939: A Study of Economic, Social and Political Problems with Particular Reference to the Experience of Burnley, Halifax, Ipswich, and Luton", (Ph.D.,University of Leeds, 1974), p. II5.

79. R.C. Whiting, The View from Cowley: The Impact of Industrialisation upon Oxford, I9I8-I939 (Oxford, 1983), pp. 39-66.

8o. Author unknown, "Letchworth - Some Economic and Industrial Aspects", typescript, I935, Letchworth Museum. 
while the Slough estate also employed a large number of such workers. ${ }^{81}$ As houses in Welwyn and Letchworth were expensive, the recruitment of cheap labour was heavily dependent on rural workers with lower accommodation costs. ${ }^{82}$ Many adult male ex-agricultural workers in Oxford and Coventry also continued to commute from their villages of origin. This assisted car manufacturers in retaining such workers despite occasional temporary layoffs during the summer slack season, as they were able to switch to harvest work rather than seek new permanent employment. ${ }^{83}$

\section{THE MIGRANT DIMENSION}

In addition to commuting, and short-distance migration, from agricultural areas to local industrial centres, the interwar years witnessed considerable longer-distance migration. ${ }^{84}$ Despite contemporary perceptions that higher postwar housing costs, stronger unions, and unemployment benefit had substantially impeded migration, estimates by Hunt and Pitfield suggest that while net interregional migration during the I920s was no greater than that over I86I-I9II, during the I930s it was substantially higher. ${ }^{85}$ Pitfield estimated that the number of net inter-county moves within Britain rose from 686,958 over 1920-1929 to I,48I,327 during 1929-1939, while net interregional moves rose from 282,994 to $772,292 .{ }^{86}$

One important migration stream was from the County of London (which experienced a net loss of 339,000 people from I92I-1935) to outer London, or beyond, often led by the decentralization of industry. ${ }^{87}$ As noted earlier, most case study centres on the fringes of London attracted substantial numbers of decentralizing firms. They also attracted considerable population migration from London, as shown by the example of Welwyn, discussed below. Many firms moving from London brought at least part of their workforce (especially skilled workers) with them. However, London was of little importance as a source of firm and population migration to more distant rapid growth centres such as Coventry. ${ }^{88}$ Another mechanism of population dispersal from London was the development of a number of major housing estates outside the County of London by London County

8I. Tyrewhitt, Welwyn Survey; Savage, "Trade Unionism”, p. 220.

82. MTCP, Welwyn Report.

83. Jonathan Zeitlin, "The Emergence of Shop Steward Organization and Job Control in the British Car Industry: a Review Essay", History Workshop Journal, Io (1980), pp. I2I-I37, I26.

84. E.H. Hunt, Regional Wage Variations in Britain: I850-19I4 (Oxford, I973), pp. 257-262.

85. Ibid. (comparing the I92I-I93I decade with those from I86I-I9II); D.E. Pitfield, "Labour Migration and the Regional Problem in Britain, 1920-1939” (Ph.D., University of Sterling, 1973), p. 48.

86. Pitfield, "Labour Migration", p. 48.

87. Dov Friedlander, "London's Urban Transition I85I-1951", Urban Studies, II (1974), pp. I27I4I; London Passenger Transport Board, Report for Year Ended 30 June 1936 (London, 1936), p. 9. 88. Shenfield and Florence, "Labour", pp. 43-45. 

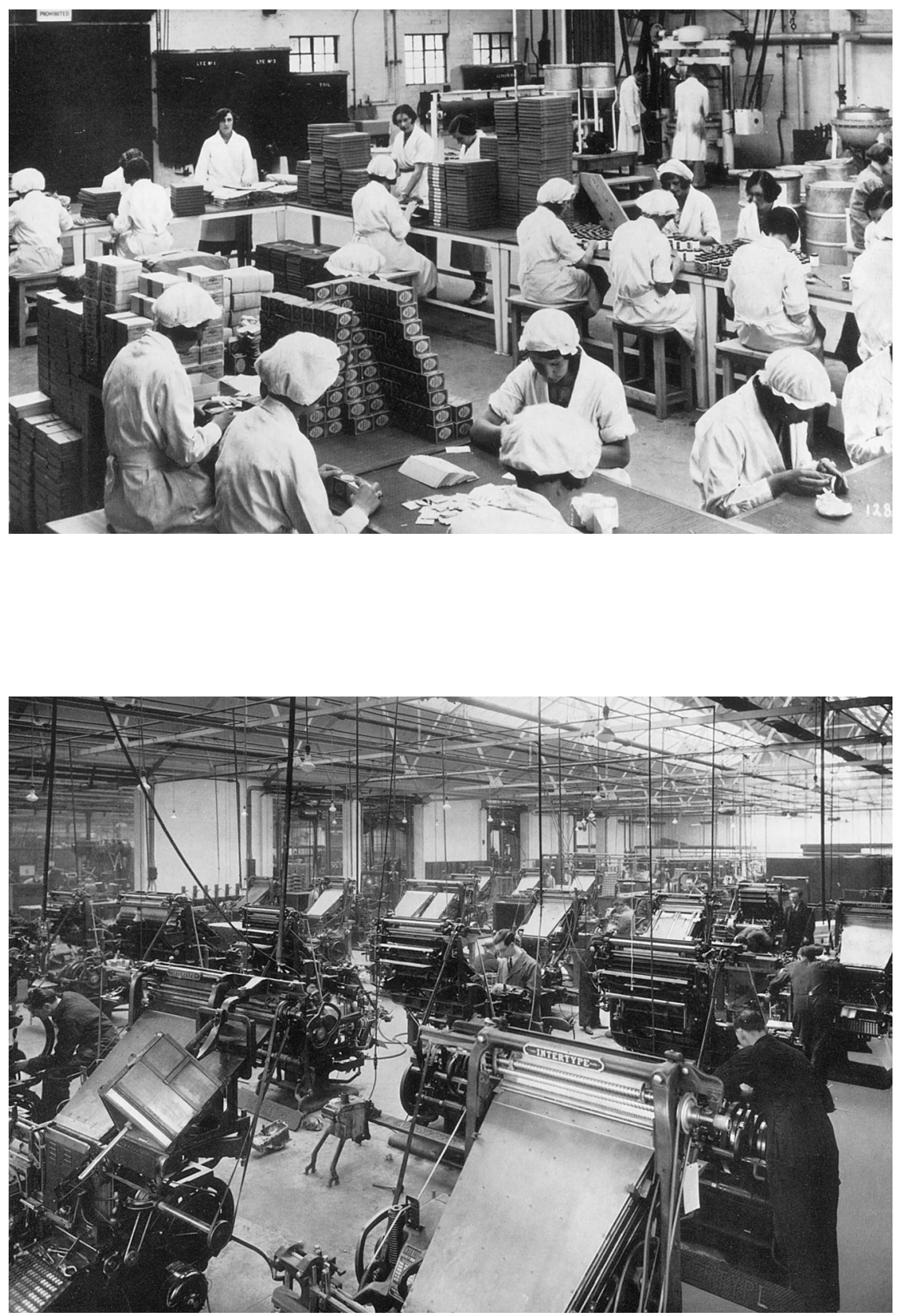

Figures 2 and 3. Labour-intensive and capital-intensive production on the Slough Estate, c. 1938: "47II" Eau de Cologne Parfumerie Fabrik (2) and Intertype Ltd (3).

Photographs from a promotional booklet: Slough Estates Ltd: London's Trading Estate (Slough, n.d. [c. 1938$]$ ). 
Council. The largest, such as as Becontree, at Dagenham (population II 2,500 ) and St. Helier, at Morden (population almost 40,000) had a considerable local impact on labour supply. ${ }^{89}$ A 194I survey indicated that 30.5 per cent of residents at Becontree and 20.I per cent at St. Helier worked within a two-mile radius of their estates. The proportions working within five miles were 58.I and 36.4 per cent respectively. ${ }^{90}$ Housing allocation policies favoured large families, providing an ample supply of juvenile workers; half the residents of Becontree, and almost half those of the Watling estate at Hendon, were under eighteen. ${ }^{9 \mathrm{r}}$

Durant's survey of the Watling estate, a cottage estate of 19,000 people designed for the "elite" of the working class, indicated that while only 26.3 per cent of Watling household heads worked in Hendon, 54.3 per cent of other employed family members worked locally. This was due to the fact that Hendon's recently established (and rapidly expanding) factory sector sought unskilled labour, rejecting "family fathers" in favour of "their wives, [...] sons and daughters"..$^{92}$ Durant divided the estate's juvenile employment geographically between the majority employed in dead-end local factory jobs and a minority whose family connections had helped them secure jobs with "prospects" in old established firms. Such jobs entailed commuting towards London's centre: "for Watling youngsters Hendon is a place where one can earn money, provided one is young enough, and London is a place which harbours prospects, provided one is rich enough to aspire to them". ${ }^{93}$ A significant correlation between a father's socioeconomic class and the employment opportunities of his children was corroborated by Baines and Johnson's analysis of the New Survey data. ${ }^{94}$ However, they found only a low level of occupational continuity between fathers and their sons and a higher degree of social mobility than was suggested by previous studies.

This period also saw substantial migration from Britain's depressed regions. According to one estimate, the Ministry of Labour's London and South East Division experienced net inmigration of I,22I,000 people over 1920-1939, while its South West and Midlands Divisions gained 222,000 and 36,000 people respectively, at the expense of Britain's northern industrial areas, Scotland, and Wales. ${ }^{95}$ The volume of internal migration, and

89. Andrzej Olechnowicz, Working-Class Housing in England Between the Wars: The Becontree Estate (Oxford, 1997), p. 2.

90. G.R. Mitchison, "Greater London Supplementary Report No. 2 - Journeys to Work", November I94I, NCSRS, CI/I05.

91. Olechnowicz, Working-Class Housing, p. 72; Ruth Durant, Watling: A Survey of Social Life on a New Housing Estate (London, 1939), pp. I2-13.

92. Durant, Watling, pp. I2-13.

93. Ibid., p. I4.

94. Dudley Baines and Paul Johnson, "In Search of the 'Traditional' Working Class: Social Mobility and Occupational Continuity in Interwar London”, Economic History Review, 52 (1999), pp. 692-713, 705-706.

95. Pitfield, "Labour Migration", pp. I20-I22. 
the relative importance of long-distance moves from the depressed industrial areas of "outer Britain", was greatest during the 1932-1937 economic recovery. ${ }^{96}$ This was a period when large regional unemployment disparities were accompanied by high labour demand in some expanding areas.

Government encouraged and assisted migration under its "industrial transference" programme, which provided a variety of benefits and training for depressed area migrants. Over the years $1928-1938$ the transference scheme assisted 339,843 moves, according to official figures which record most (but not all) those who received government financial assistance. Many other migrants received advice from the employment exchange system regarding migration and/or were placed in their first job in the centre to which they migrated by its local employment exchange. Reception area exchanges had been given target numbers of depressed area workers to place and some took such workers to the front of the queue for vacancy placements. ${ }^{97}$

New and expanding industries generally preferred local female, juvenile, and ex-agricultural workers to migrants from depressed areas, on account of their cheapness, flexibility, and low perceived industrial militancy. ${ }^{98}$ However, rapidly expanding centres eventually experienced shortages of such labour and were forced to turn to migrants. This process is illustrated by the development of Welwyn. In 1929, when Welwyn's population was around 8,000, a survey noted that unskilled adult male workers were still easily obtainable locally and from neighbouring towns, though much greater difficulty was experienced in obtaining female and juvenile labour. ${ }^{99}$ Thirty per cent of Welwyn's "working-class" ${ }^{\text {"10o }}$ households were estimated to have come from London, 52 per cent from within a twelve-mile radius of Welwyn, and only i8 per cent from the rest of Britain. ${ }^{\text {Ior }}$ In 1939, when Welwyn's population had grown to around I4,IOo, a further survey indicated that, as in 1929, 30 per cent of working class families came from Greater London. However, only 20.2 per cent came from Hertfordshire, while 49.8 per cent were from elsewhere in Britain (34.3 per cent from the north, Scotland, and Wales). ${ }^{102}$ At Slough, migrants from south Wales alone were estimated at I0,000 to II,000, out of a population of around 60,000,

96. Brinley Thomas, "The Influx of Labour into London and the South East 1920-1936", Economica, 4 (1937), pp. 323-336, 330 .

97. "Report of Enquiry into the Industrial Transference Scheme (Adults), Part II", June I938, PRO, LAB8/218.

98. Dennison, Location of Industry, p. 78; Zeitlin, "Emergence".

99. LSE, New Survey of London Life \& Labour, vol. 6: Survey of Social Conditions (2) The Western Area (London, 1934), p. 257; "The Movement of Industry and Labour to Welwyn Garden City", research report, November 1929, Welwyn Garden City Library, Sir Frederic Osborn Archive, Kio9.

Ioo. The sample included some lower-paid clerks and civil servants.

IOI. LSE, New Survey of London Life \& Labour, vol. 6, pp. 254-256.

IO2. Tyrewhitt, Welwyn Survey. 
by the late I930s; 83 per cent of Luton's I92I-I939 population increase was estimated to represent in-migration; while the proportion of migrants in Coventry's 1935 population was estimated at 40 per cent. ${ }^{103}$ Analysis of insured workers' employment books ${ }^{\mathrm{I} 4}$ at Coventry indicates that at least 5I per cent of male and 48.6 per cent of female in-migrants over 1920-1939 came from depressed areas dominated by staple industries.

Those migrants most in demand were women and juvenile, or young adult male, workers, who were the cheapest, most flexible, and least unionized segment of the migrant workforce. Migration is generally dominated by younger workers. Industrial transference accentuated this inherent bias by providing income support for those migrant juveniles who received wages below subsistence levels; 6I.9 per cent of boys and 20.4 per cent of girls transferred to industrial employment over 1933-1938 were subsidized in this way, ${ }^{105}$ subsidies being particularly important for younger juveniles whose low wages otherwise severely restricted geographical mobility. Over 19331938 boys and girls (aged fourteen to eighteen) accounted for I7.4 and I7.2 per cent of official transferees respectively, the total proportion of juveniles being almost four and a half times their proportion of the national insured population. Meanwhile an additional 22.I per cent of official transferees during $1933-1936$ were adult women. ${ }^{\mathrm{I} 6}$

Juvenile male transferees were said to be an important source of labour for firms at Coventry and Dagenham, allowing employers to keep wages down. ${ }^{107}$ However, the majority of long-distance migrants were young (but not juvenile) men; these were particularly important in areas such as Slough, Letchworth, and Watford, where government training centres (established to train male transferees aged eighteen to thirty-five in skilled trades) acted as major ports of entry to local labour markets. The rapid inflow of migrants to such centres, assisted by the transference initiative and the employment exchange system, played an important role in keeping adult male wages at or below the national average, despite their rapid industrial growth. ${ }^{108}$ In common with their hostility to competition from female and juvenile

I03. South Wales and Monmouthshire Council of Social Service, memoranda, June I937 and c. 1939, London Metropolitan Archives, Acc. 2720/or/o7/oI, National Council of Social Service papers; Smithies, "Contrast between North and South", pp. I56-157; Bill Lancaster, "Whose a Real Coventry Kid? Migration into Twentieth Century Coventry”, in Lancaster and Mason, Life and Labour, pp. 57-80, 70.

I04. Documents recording workers for the unemployment insurance scheme.

I05. UK Parliament, Ministry of Labour, Annual Report (London, 1934-1939); excludes boys transferred through vocational training schemes and girls transferred to domestic employment.

I06. Peter Scott, "The State, Internal Migration, and the Growth of New Industrial Communities in Interwar Britain", English Historical Review, II5 (2000), pp. 329-353.

I07. Carr, "Engineering Workers", p. 438; minutes of conference of union representatives interested in the organization of workers at Ford, Dagenham, Io January 1937, Modern Records Centre, Warwick, TUC papers, Mss. 292/57.4/13.

I08. Scott, "The State". 
labour, local adult male workers and their unions generally opposed the employment of migrants from depressed regions, who were associated with deskilling and undercutting local wage rates. Acute social friction between local workers and in-migrants (especially the Welsh, who had the greatest perceived social difference to their host populations) was reported in a number of centres of high in-migration. ${ }^{\text {109 }}$

\section{CONCLUSIONS}

Major innovations in manufacturing organization and technology often lead employers to draw workers from the reserve army of labour in order to overcome worker resistance to the new methods and provide a cheap and flexible workforce. For example, as Berg and Hudson have noted, the Industrial Revolution saw considerable absorption of female and juvenile labour into commercial production (especially with regard to new forms of productive organization). ${ }^{\text {II }}$ With regard to the more recent past, Massey has argued that during the 1960s and I970s the British economy experienced a similar rejection of the established manufacturing workforce by industries which shifted location in order to employ less unionized and cheaper female and other labour. ${ }^{\text {III }}$ The interwar years therefore represent one in a series of episodes in which the introduction of new technology, associated deskilling, and changes in industrial location allowed employers to reject the existing industrial workforce in favour of cheaper and more flexible labour.

Marx classified the reserve army as taking three main forms: the floating (workers in insecure industrial employment), the latent (workers attracted from nonindustrial sectors offering inferior pay and conditions), and the stagnant (marginal and underemployed industrial workers such as outworkers). ${ }^{\mathrm{II}}$ Employers in secondary labour markets generally preferred juvenile workers, and then women, on account of their low wages and flexibility, while their counterparts in primary labour markets preferred reliable workers with low labour turnover but without industrial experience or unionization, such as former agricultural workers. These groups of workers were drawn mainly from the latent reserve. Only when industrial growth was sufficient to exhaust the local supply of such workers was the floating reserve - in the shape of long-distance migrants formerly employed in the staple industries - called upon in substantial numbers by employers in either primary or secondary labour markets. Unlike the latent reserve, staple industry migrants often had established ideas and expectations regarding unionization, wages, and conditions. Thus employers preferred local cheap workers

I09. Ibid.

IIO. Maxine Berg and Pat Hudson, "Rehabilitating the Industrial Revolution", Economic History Review, 2nd series, 45 (1992), pp. 24-50, 36-37.

III. Massey, Spatial Divisions of Labour, pp. 292-293.

II2. Marx, Capital, vol. I, pp. 600-602. 
or those migrants from depressed areas who, through youth, had no significant industrial experience.

The composition of the new industrial workforce casts further doubt on the "old optimist" thesis, based around the work of Aldcroft and Richardson, that the market mechanism offered a long-term solution to Britain's interwar economic problems via a process of structural readjustment. They argued that the transfer of resources from old to new sectors provided a long-term solution to Britain's unemployment problem (though the employment transfer was viewed as having been delayed by the new industries being more capital-intensive than the declining staples - a claim which has been challenged by subsequent research). ${ }^{\amalg 3}$ In fact, despite an increase in manufacturing employment of around 565,000 from 1923-1938, relatively few of the jobs created went to displaced staple industry workers. Not only were the new jobs in different regions from those of the declining industries, the very nature of the jobs themselves placed adult male workers with significant industrial experience at a considerable disadvantage compared to cheaper workers or those perceived to be more flexible. ${ }^{\text {II }}$ Only in the most rapidly expanding centres was employment growth sufficient to outstrip the supply from the latent reserve of labour and force employers to recruit substantially from the floating reserve.

II3. Derek H. Aldcroft and H.W. Richardson, The British Economy I870-1939 (London, I969); G.N. von Tunzelmann, "Structural Change and Leading Sectors in British Manufacturing 190768", in Charles P. Kindleberger and Guido di Tella (eds), Economics in the Long View: Essays in Honor of W.W. Rostow (London, 1982), pp. I-49; Stephen N. Broadberry, "Unemployment in Interwar Britain: a Disequilibrium Approach”, Oxford Economic Papers, 35 (1983), pp. 463-485. II4. The employment exchange system did attempt to counteract this, by prioritizing the placement of migrants from depressed areas - see Scott, "The State". 